\title{
PEMBUDAYAAN NILAI-NILAI PENDIDIKAN AGAMA ISLAM MULTIKULTURAL PADA AKADEMI KEPERAWATAN PEMERINTAH KABUPATEN GRESIK
}

\author{
Elvi Wahyudi \\ Dinas Pendidikan Provinsi Jawa Timur Wilayah Gresik \\ Email : elviwahyudi195@gmail.com
}

\begin{abstract}
Abstrak
Keperawatan merupakan salah satu bentuk pelayanan kesehatan. Selain diharapkan meningkatkan dan mengembangkan potensi dalam pelayanan kesehatan, dalam konteks Keberagaman (multikultural) perawat juga dituntut mampu memberikan pelayanan sesuai dengan nilai-nilai Islam. Jenis penelitian adalah kualitatif dengan pendekatan etnografi yang mengambil setting di Akademi Keperawatan Pemerintah Kabupaten Gresik. Teknik pengambilan data yang dilakukan menggunakan teknik wawancara, observasi, dan studi dokumentasi. Implikasi hasil penelitian ini secara berhubungan dengan teori nilai pendidikan agama Islam berbasis multikultural dalam dunia keperawatan sedangkan secara praktis berimplikasi terhadap Akademi Keperawatan Pemerintah Kabupaten Gresik dalam rangka pembinaan mahasiswa yang beraneka sebagai persiapan profesi sebagai perawat harus memiliki pengaruh terhadap tingkah laku, sikap dan pola pikir. Demikian juga bagi pihak pemerintah baik pemerintah daerah, provinsi maupun pusat dalam pengembangan nilai-nilai pendidikan agama Islam multikultural.
\end{abstract}

Kata kunci: keperawatan, multikultural, nilai-nilai, pelayanan, Islam

\section{Abstract}

The study of Multicultural Islamic Education in the multicultural society's social interaction relationship in Laban illustrates the social interactions of the people of Laban which have educational values of children and succeding generations. The findings of this study are; 1) the existance of the multicultural character of the people of Laban through the habit of imitating the prevailing traditions of ancestors and imitating what parents do and commanded. 2) there is no balance between literal / textual with contextual learning. From these findings, can be taken lesson in the education theory as follows: 1) multiculturalism in the character of society will be better if more often conduct social interaction activities. 2) There is a need for a balance between text and context to produce moderate education. Because the education that is conduct through experience and giving examples of reality will produce a realistic understanding, but there is no detailed 
explanation yet. Meanwhile, the development of education conducted through the understanding and delivery of material according to the literature will generate theoretical knowledge, has not guaranteed appropriate in its implementation in reality.

Keywords: nursing, multicultural, values, service, Islam

\section{PENDAHULUAN}

Keperawatan merupakan salah satu bentuk profesi yang memberikan pelayanan kesehatan terhadap pasien. Dalam implementasi tugas dan fungsinya sebagai perawat, tentu peningkatan dan pengembangan potensi dalam memberikan pelayanan kesehatan harus terus dikembangkan karena perubahan situasi dan kondisi masyarakat yang sangat dinamis. Selain dituntut peningkatan dan pengembangan potensi, perawat harus mampu memberikan pelayanan tentang keadaan individu pasien baik dari segi bio, psiko, sosial dan spiritual. Masing-masing faktor ini mempengaruhi pembentukan lembaga pendidikan umum seperti pengembangan (promosi reformasi) lembaga pendidikan khusus. ${ }^{1}$

Dalam konteks pembudayaan nilai-nilai pendidikan agama Islam multikultural pada Akademi Keperawatan Pemerintah Kabupaten Gresik, pembudayaan nilai-nilai pendidikan agama Islam menawarkan satu alternatif melalui penerapan strategi dan konsep pendidikan yang berbasis pada pemanfaatan keragaman yang ada di masyarakat, khususnya yang ada pada mahasiswa seperti, keragaman etnis, budaya, bahasa, agama, status sosial, gender, kemampuan, umur dan ras. Adapun yang terpenting, strategi pendidikan ini tidak hanya bertujuan agar mahasiswa mudah memahami perkuliahan yang dipelajarinya, tetapi juga untuk meningkatkan kesadaran mereka agar selalu berperilaku humanis, pluralis dan demokratis. Oleh karena itu, percepatan pembangunan di negara manapun terkait erat dengan peran dan pengembangan pendidikannya. ${ }^{2}$

Penelitian ini bertujuan mencari temuan-temuan untuk dianalisis, dipahami dan dideskripsikan hal-hal sebagai berikut : mendeskripsikan nilai pendidikan agama Islam multikultural apa saja yang dikembangkan pada Akademi Keperawatan Pemerintah Kabupaten Gresik; mendeskripsikan proses pembudayaan nilai pendidikan agama Islam kultural terhadap mahasiswa Akademi Keperawatan Pemerintah Kabupaten Gresik; mendeskripsikan model pembudayaan nilai pendidikan agama Islam multikultural pada Akademi Keperawatan Pemerintah Kabupaten Gresik

\footnotetext{
${ }^{1}$ Mujamil Qomar,. Pesantren: dari Transformasi Metodologi Menuju Demokratisasi Institusi. (Jakarta: Erlangga, 2033), 98.

${ }^{2}$ Haidar Putra Daulay, Sejarah Pertumbhan dan Pembaruan Pendidikan Islam di Indonesia. (Jakarta: Kencana Prenada Media Group, 2009), 68.
} 


\section{METODE PENELITIAN}

Jenis penelitian kualitatif menjadi pilihan karena dalam penelitian ini akan memahami makna yang mendasari tingkah laku partisipan, mendeskripsikan latar dan interaksi komplek, eksplorasi untuk mengidentifikasi tipe-tipe informasi, dan mendeskripsikannya. Menurut Kirt dan Miller bahwa penelitian kualitatif adalah tradisi tertentu dalam ilmu pengetahuan sosial yang secara fundamental tergantung pada pengamatan terhadap manusia dalam kawasannya sendiri dan berhubungan dengan orang-orang tersebut dalam bahasannya dan dalam peristilahannya. ${ }^{3}$

Penelitian ini juga dilakukan dengan cara menuliskan, mengklarifikasikan dan menjadikan data yang diperoleh dari berbagai sumber tertulis. Kemudian menganalisis sumber-sumber literatur yang berkaitan dengan materi dan difokuskan pada penelaahan masalah yang dibahas. ${ }^{4}$ Pendekatan penelitian ini adalah etnografi karena menceritakan kembali perilaku-perilaku, peristiwa-peristiwa, kondisi sosial ekonomi pasa suatu kelompok masyarakat budaya tertentu.

Data dikumpulkan melalui wawancara, teknik pemantauan dan dokumentasi. Teknik analisis data meliputi reduksi data, interpretasi data, tampilan data, validasi data, dan pemetaan kesimpulan Hasil divalidasi melalui teknik triangulasi, pengujian anggota, teknik diskusi, analisis kasus negatif, dan waktu pencarian yang diperpanjang.

\section{PEMBAHASAN}

Paparan data dalam penelitian pembudayaan nilai-nilai pendidikan agama Islam multikultural pada Akademi Keperawatan Pemerintah Kabupaten Gresik ini berisi tentang informasi yang dihasilkan oleh peneliti dari kegiatan pengolahan atau analisis data yang telah dikumpulkan dari hasil pengamatan (apa yang terjadi atau peristiwa yang diamati melalui pancaindera), hasil wawancara (apa yang dikatakan oleh informan), serta deskripsi informasi lainnya (misalnya yang berasal dari dokumen seperti program kerja, silabus, rencana pelaksanaan pembelajaran, foto, rekaman video dan hasil pengukuran). Untuk itu, pada bagian ini hanya ada kutipan dari hasil wawancara, observasi, dokumen. Catatan penting dalam bagian observasi memaparkan informasi dari peristiwa yang diamati dan berkaitan langsung dengan fokus penelitian yang dicarikan jawabannya.

${ }^{3}$ Maman Rachman, Strategi dan Langkah-langkah Penelitian. (Semarang: IKIP Semarang Perss, 1999), 20.

${ }^{4}$ Noeng Muhajir, Motede Penelitian Kualitatif, Edisi II, cet. Ke-8 (Yogyakarta: Rake Sarasin, 1983),:43 
Nilai-nilai pendidikan agama Islam multikultural yang dikembangkan melalui rencana pembelajaran semester atau RPS mata kuliah pendidikan agama Islam Akademi Keperawatan Pemerintah Kabupaten Gresik bertujuan untuk menghasilkan lulusan yang siap pakai menjadi seorang yang berprofesi sebagai perawat. Sebagai seorang perawat, karakter nilai-nilai pendidikan agama Islam yang sesuai dengan keperawatan harus dikembangkan. Implementasi nilai yang dikembangkan melalui mata kuliah pendidikan agama Islam direncanakan dalam proses menuju hasil, misalnya demontrasi, diskusi kelompok serta praktikum dalam menangani pasien dalam bentuk fragmen. Dari segi prosesnya, alIkha' (persaudaraan), al-musawah (persamaan), al-tasamuh (toleransi), altasyawur (musyawarah), al-ta'awun (tolong menolong) dan al-'adalah (keadilan) ditemukan dalam perencanaan kurikulum, terutama dalam demontrasi, diskusi kelompok serta praktikum dalam menangani pasien dalam bentuk fragmen, setiap mahasiswa mengalami aktivitas bersosialisasi dengan mahasiswa yang beragam serta memiliki hak yang sama dalam berpendapat sehingga tercipta suasana yang demokratis, adil, dan terbuki. Dengan demikian diidealisasikan mampu memenuhi harapan masyarakat yang dilayani dalam melaksanakan tugas pelayanan publik (pelayanan publik) dan pengembangan komunitas (pengembangan komunitas). ${ }^{5}$

Proses dalam hubungan-hubungan sosial yang mengarah pada nilainilai pendidikan agama Islam multikultural terjadi pada saat para mahasiswa Akademi Keperawatan Pemerintah Kabupaten Gresik yang mendapatkan perkuliahan pendidikan Agama sebagai persiapan profesi sebagai perawat. Lulusan Akademi Keperawatan Pemerintah Kabupaten Gresik yang berprofesi di rumah sakit akan berhadapan dengan pasien dari berbagai budaya, tak terkecuali masalah agama. Manifestasi proses pembudayaan nilai-nilai pendidikan agama Islam dilalui oleh perawat dengan belajar dari realitas dan pengalaman saat dia mendapatkan perkuliahan di bangku kampus. Hal ini sedikit banyak berpengaruh terhadap terciptanya perubahan interaksi sosial yang efektif. Dalam perkuliahan pendidikan agama Islam harapan berbeda mengenai identitas serta cara pandang yang ditampilkan berpotensi menimbulkan kegelisahan, kesalahpahaman, dan bahkan konflik. Oleh karena itu, perlunya sebuah pemahaman kepada para mahasiswa nilainilai pendidikan agama Islam. Hal ini penting, karena kondisi ini merupakan bagian tidak ak terpisahkan dalam mengelola dan menjalankan institusi pendidikan. Menurut Mulyasa Manajemen mahasiswa atau manajemen

5 Umiarso dan Nur Zazin. Pesantren di Tengah Arus Mutu Pendidikan Menjawab Problematika Kontemporer Manajemen Mutu Pesantren. (Semarang: Rasail Media Group, 2011), 7. 
mahasiswa (mahasiswa) merupakan salah satu bidang manajemen pendidikan $^{6}$

Data pengembangan model pendidikan karakter berbasis multikultural dilakukan peneliti pada seluruh kegiatan kampus mulai dari proses perkuliahan maupun kegiatan ekstrakurikuler dan pengembangan diri yang dilakukan di luar kampus, senantiasa diwarnai oleh pendidikan karakter berbasis multikultural Model pembudayaan nilai-nilai pendidikan agama Islam multikultural pada Akademi Keperawatan Pemerintah Kabupaten Gresik ditemukan model prinsip pendidikan karakter. Pendidikan dalam pembentukan karakter ini tidak lepas dari pendidikan agama Islam yang dikembangkan di kampus karena model ini akan mengimplementasikan beberapa nilai-nilai pendidikan agama Islam multikultural atau nilai-nilai multikultural. ${ }^{7}$

Secara genral dipahami, bahwa pendidikan merupakan layanan yang diberikan kepada masyarakat untuk mengembangkan fokus diri secara kompetensi yang meliputi kemampuan kognitif, afektif, dan psikomotorik. Pendidikan merupakan proses dalam membina dan mengembangkan aspek spritual, moral dan intelektual ${ }^{8}$

Nilai-nilai pendidikan agama Islam yang dikembangkan terimplementasi dalam program rencana perkuliahan semester (RPS) mata kuliah pendidikan agama Islam secara umum dirancang untuk mendorong minat mahasiswa sekaligus mempersiapkan mahasiswa untuk menjadi ilmuwan dan professional yang beriman dan bertaqwa kepada Tuhan Yang Maha Esa, berakhlak mulia, dan memiliki etos kerja, serta menjunjung tinggi nilai-nilai kemanusiaan dan kehidupan. Secara khusus bertujuan membantu mahasiswa memantapkan kepribadiannya agar secara konsisten mampu mewujudkan nilai-nilai dasar keagamaan dan kebudayaan, rasa kebangsaan dan cinta tanah air sepanjang hayat dalam menguasai, menerapkan dan memngembangkan ilmu pengetahuan, teknologi dan seni yang dimilikinya dengan rasa tanggung jawab sesuai dengan tuntunan dan ajaran Islam dalam kehidupan sehari-hari.

Dalam dunia keperawatan, rancangan perkuliahan semester (RPS) mata kuliah pendidikan agama Islam memasukkan unsur pengembangan nilai-nilai Islam. Nilai-nilai tersebut penting dikembangkan karena perawat memiliki fungsi yang strategis untuk menjadi sumber kekuatan moral bagi pasien dalam proses pelayanan sekaligus upaya penyembuhan. Akademi

${ }^{6}$ E. Mulyasa, Manajemen Berbasis Sekolah. (Bandung: Rosdakarya, 2009), 4.

${ }^{7}$ Muhammad Tholchah Hasan,. Pendidikan Multikultural Sebagai Opsi Penanggulangan Radikalisme. (Malang: Lembaga Penrbitan UNISMA, 2016). 45-46.

${ }^{8}$ A, Doni Koesoema. Pendidikan Karakter Strategi Mendidik Anak di Zaman Global. (Jakarta: PT Gramedia. 2010), 52. 
Keperawatan Pemerintah Kabupaten Gresik merupakan lembaga pendidikan yang mencetak lulusan dengan profesi kemanusiaan yang berkecimpung dalam dunia kesehatan. Dalam mempersiapkan lulusannya Akademi Keperawatan Pemerintah Kabupaten Gresik memberikan prepare terhadap lulusannya berupa sikap, moral, etika terhadap pasien terutama masalah agama. Tentu, nilai-nilai pendidikan agama Islam merupakan hal yang penting untuk diketahui, dipahami, bahkan dikembangkan oleh mahasiswa dalam rangka pemberian penanganan pasien yang beraneka asal usulnya tak terkecuali masalah agama.

Dari data yang dapat peneliti kumpulkan dari beberapa mahasiswa Akademi Keperawatan Pemerintah Kabupaten Gresik dari proses perkuliahan sebagai berikut: Salah satu pokok bahasan mata kuliah agama yaitu memahami pengertian, iman, fungsi, kedudukan dan motivasi orang beragama bagi kehidupannya sesuai agama dan keyakinannya. Secara umum tuntutan untuk mampu menjelaskan pengertian agama, menjelaskan fungsi agama dalam kehidupan, menjelaskan kedudukan agama bagi kehidupan, dan menjelaskan motivasi dan tujuan beragama. Bersama temanteman kelompok, diwajibkan menyelesaikan tugas berupa pembuatan makalah. Dalam pembahasan diskusi antarteman, berjalan sesuai dengan langkah-langkah yang disampaikan dosen pengampu agama Islam dan berjalan dengan sikap sangat toleransi dengan mengedepankan nilai al-Ikha' (persaudaraan), al-musawah (persamaan), al-tasamuh (toleransi), altasyawur (musyawarah), al-ta'awun (tolong menolong) dan al-'adalah (keadilan) yang dikembangkan pada Akademi Keperawatan Pemerintah Kabupaten Gresik.Nilai-nilai yang berhubungan langsung dengan nilai-nilai pendidikan agama Islam yang dikembangkan selaras dengan nilai keperawatan bedasarkan The Public Relation Society Of America yaitu, a. altruisme

Altruisme adalah kepedulian terhadap kesejahteraan orang lain. Sikap Altruisme ini biasanya diterapkan oleh seorang perawat untuk kesejahteraan pasien, perawat lain, dan penyedia layanan kesehatan lain Sikap altruisme ini diterapkan oleh mahasiswa Akademi Keperawatan Pemerintah Kabupaten Gresik. Data yang terkumpul melalui observasi ketika mahasiswa melihat pasien dalam keadaan bingung mencari informasi mengenai proses pengobatan mahasiswa dengan senang hati membantu mencarikan informasi tersebut. Sikap empati juga ditunjukkan terhadap teman yang sedang bersedih dengan memberikan, bimbingan, dan mencarikan solusi ketika ia sedang mempunyai masalah. Selain terhadap orang yang lebih muda kita juga bisa menerapkan sikap altruisme kepada keluarga dan masyarakat ataupun mahasiswa lainnya dengan bersikap sukarela jika dimintai bantuan, tidak mengharapkan 
imbalan, dan dilakukan semata-mata untuk saling membantu dan berbuat kebaikan.

b. Otonomi

Otonomi adalah hak individu untuk menentukan nasibnya sendiri. Perawat memberikan kebebasan kepada pasien untuk menentukan perawatan kesehatannya sendiri. Sikap otonomi terdapat komponen keyakinan, harapan, kemandirian, keterbukaan, dan disiplin diri. Mahasiswa Akademi Keperawatan Pemerintah Kabupaten Gresik menerapkan sikap otonomi dengan keterbukaan kepada siapa pun tak terkecuali kepada seorang pasien serta menghargai apapun keputusan mereka.

c. Human dignity

Rasa hormat terhadap nilai dan keunikan masing-masing individu dan populasi. Menghargai martabat manusia adalah salah satunya dengan menjaga rahasianya, seperti seorang perawat menjaga rahasia penyakit si pasien. Mahasiswa Akademi Keperawatan Pemerintah Kabupaten Gresik diharapkan dapat menerapkan nilai human dignity dengan menjaga rahasia temannya jika dia bercerita tentang privasinya, ataupun bisa dengan menumbuhkan rasa saling percaya antara mahasiswa kepada mahasiswa, orang yang lebih tua, muda, maupun kepada keluarga.

d. Integritas

Integritas yaitu bergerak atau mengambil tindakan sesuai dengan kode etik yang berlaku, Integritas tercemin dalam praktik perawat, perawat bertindak jujur dan melakukan tindak keperawatan bedasarkan kerangka etis yang berlaku dalam profesinya. Nilai integritas di keperawatan ini bisa dilakukan oleh mahasiswa kepada masyarakat luas atau kepada keluarganya dengan selalu mematuhi aturan yang berlaku, mengikuti budaya dan etika yang telah menjadi kebiasaan di lingkungannya, selalu menghormati orang yang lebih tua, mengayomi orang yang lebih muda, dan menyayangi sesama.

e. Adil

Adil, bertindak sesuai dengan perlakuan yang adil, terlepas dari status ekonomi, ras, etnis, usia, kewarganegaraan, kecacatan, atapun orientasi seksual. Sebagai mahasiswa kita bisa menerapkan keadilan dengan tidak membeda-bedakan teman, bersikap baik pada siapa saja, peduli, dan terbuka kepada siapapun tanpa memandang ras, etnis, status sosial. Sebagai mahasiswa yang menjujung tinggi nilai keadilan, penerapan sikap tidak hanya diterapkan di lingkungan kampus tetapi di lingkungan keluarga dan masyarakat.

f. Estetika 
Estetika adalah kualitas objek, kejadian, manusia yang mengarah kepada pemberian kepuasan dengan perilaku ataupun sikap yang ditunjukan dengan adanya apresiasi, kreativitas, imaginasi, dan sensitifitas.Sikap estetika ini juga mencakup penampilan seorang perawat itu sendiri, apakah pakaian yang dikenakan rapih dan bersih, apakah penampilannya itu dapat membuat pasien nyaman melihatnya atau malah sebaliknya, karena penampilan bagi seorang perawat adalah aspek yang cukup penting untuk diperhatikan.Begitu pula dengan seorang mahasiswa, penampilannya di depan masyarakat dan keluarganya juga merupakan aspek yang penting untuk diperhatikan, karena dengan penampilan yang rapih, bersih, harum, dan nyamam untuk dilihat, itu akan membuat dosen nyaman berada disekitarnya, tidak hanya dosen, masyarakat, keluarga, dan teman-temanya pun pasti merasa nyaman akan penampilannya. Disebutkan bahwa aspek dari estetika itu sendiri adalah kreativitas, apresiasi, dan sesitifitas. Maka kita sebagai mahasiswa harus bisa meningkatkan tingkat sensitifitas kita terhadap lingkungan, keluarga, maupun masyarakat sekitar.

g. Kebenaran

Kebenaran, sebagai seorang perawat kita harus senantiasa bertindak jujur sesuai dengan fakta dan realitanya, selalu bertanggung jawab dalam memberikan informasi yang benar. Penerapan nilai kebenaran ini harus diterapkan oleh mahasiswa baik itu di lingkungan kampus, keluarga, maupun masyarakat, dan lingkungan tempat tinggalnya. Contoh penerapannya adalah ketika orang tua bertanya, kita senantiasa menjawabnya dengan jujur, sesuai dengan realita, serta tidak berbohong hanya untuk menyenangkan hati orang tua.

Untuk mewujudkan keberhasilan proses pembudayaan dibutuhkan proses pembebasan dan proses belajar agar dapat membangkitkan kesadaran kritis dan pembebasan. Banyak pendidik lebih konsentrasi pada metode ketika proses belajar diselenggarakan namun sesungguhnya pendidikan tidak pernah berdiri bebas tanpa berkaitan secara dialektis dengan lingkungan dan sistem sosial di mana pendidikan diselenggarakan. Proses pendidikan sebagai proses pembebasan tidak pernah terlepas dari sistem dan struktur sosial, yakni konteks sosial yang menjadi penyebab atau yang menyumbangkan proses dehumanisasi dan keterasingan pada waktu pendidikan itu diselenggarakan.

Melalui proses pelaksanaan perkuliahan, nilai pendidikan agama Islam yang perlu dikembangkan pada Akademi Keperawatan Pemerintah Kabupaten Gresik dengan proses pendidikan kritis melalui tahapan belajar dari realitas atau pengalaman, tidak menggurui, dialogis dalam pembelajaran, mahasiswa akan dihadapkan pada tantangan bagaimana 
mengkaitkan konteks dan analisis isinya untuk memahami globalisasi secara kritis. Dalam proses belajar mengintegrasikan analisis globalisasi dan bagaimana mereka berperan dengan proses kritik dan melakukan dekonstruksi, untuk menemukan solusi alternatif terhadap globalisasi, misalnya menciptakan diskursus tandingan terhadap diskursus globalisasi yang dominan dengan perspektif alternatif dan juga membuat pendidikan kritis. Mahasiswa selepas paripurna dari kampus dan berniat mengabdikan menjadi profesi perawat harus memiliki pengetahuan dan pemahaman nilainilai pendidikan agama Islam. Disinilah manajemen dijalankan. Terry (2000) mengacu pada manajemen sebagai proses khas perencanaan, pengorganisasian, memobilisasi dan mengawasi tindakan yang diambil untuk mengidentifikasi dan mencapai tujuan yang telah ditentukan melalui penggunaan sumber daya manusia dan sumber daya lainnya. ${ }^{9}$

Perencanaan kualitas pendidikan merupakan faktor penentu dalam keberhasilan mencapai kualitas output. Jika sebuah institusi gagal untuk merencanakan kualitas, itu berarti bahwa lembaga tersebut Rencanakan kegagalan itu sendiri. Kegagalan kualitas terjadi karena kegagalan perencanaan. Kualitas tidak terjadi sendirian, harus direncanakan, dan kualitas harus menjadi strategi perusahaan dan harus ditangani dengan proses perencanaan yang matang. Tanpa perencanaan yang matang, lembaga tidak akan dapat mencapai peningkatan kualitas. ${ }^{10}$

Dalam konteks pembudayaan nilai-nilai multikultural dalam dunia keperawatan implementasi atau pelaksanaan suatu konsep yang sangat kompleks karena pelaksanaan kegiatan pendidikan ini memerlukan kontribusi dan sumbangsih dari semua pihak. Dalam pembudayaan nilainilai pendidikan agama Islam yang berbasis multikultural, masalah karakter merupakan hal yang urgen karena perawat sebagai ujung tombak dari pelayanan kesehatan yang diharapkan mempunyai karakter sebagai pelayan kesehatan yang kuat, sehingga dapat memberikan pelayanan kesehatan tersebut secara maksimal, bukan hanya berdasarkan standar dari penyelenggara pemberian layanan kesehatan, tetapi juga berdasarkan standar kepuasan pasien dan keluarganya selaku pemakai jasa pelayanan kesehatan tersebut. Oleh karena itu, perlu model pembudayaan agar nilainilai pendidikan agama Islam multikultural dapat terbentuk dengan baik,

${ }^{9}$ George R. Terry, Prinsip-Prinsip Manajemen. (edisi bahasa Indonesia). (Bandung: PT. Bumi Aksara, 2000), 1.

10 Edward Sallis,. Manajemen Mutu Terpadu Pendidikan. (Jogjajakarta: IRCiSoD, 2012), 12. 
Model pembudayaan pendidikan agama Islam tersebut adalah sebagi berikut:

a. Pendekatan Pedagogis dan Psikologi

Model pembudayaan pendekatan ini memiliki pandangan bahwa mahasiswa sebagai peserta didik adalah makhluk Tuhan yang berada dalam proses perkembangan dan pertumbuhan rohaniah dan jasmaniah yang memerlukan bimbingan, tuntunan, dan pengarahan melalui proses kependidikan. Model Pembudayaan nilai-nilai pendidikan agama Islam dengan Pendekatan Pedagogis dan Psikologis mencakup lima faktor. Lima faktor tersebut sebagai berikut

(1). Faktor Dosen Pengampu

Sebagai pengendali dan pengarah proses pembudayaan nilainilai pendidikan Islam serta pembimbing perkembangan dan pertumbuhan para mahasiswa, dosen agama Islam dituntut memahami kebutuhan perkembangan dan pertumbuhan mahasiswa untuk persiapan mahasiswa Akademi Keperawatan Pemerintah Kabupaten Gresik yang akan terjun melayani pasien di rumah sakit. Dosenagama Islam diharapkan tidak hanya mentransfer ilmu pengetahuan melainkan juga mentransformasikan tata-nilai Islami ke dalam pribadi mereka sehingga mapan dan menyatu serta mewarnai prilaku mereka sebagai pribadi yang bernafaskan Islam

(2). Faktor Peserta Didik

Mahasiswa adalah peserta didik yang sangat memerlukan bimbingan dan pengarahan yang konsisten dari seorang dosen agar apa yang diharapkan mampu berhasil dengan maksimal. Tentunya melalui pembudayaan nilai-nilai perlu ,mendapat perhatian. Selain itu, para mahasiswa harus diberi peran melalui berbagai kesempatan yang tepat, karena proses kependidikan untuk mengembangkan ciriciri individual mereka berdasar atas kemampuan dari komponenkomponen fitrahnya harus didorong ke arah perkembangan positif dan konstruktif bagi kepentingan dirinya. Dorongan atau motivasi, persuasi atau rangsangan yang positif dan koastruktif itu diberikan kepada mereka berdasarkan hukum-hukum mekanisme perkembangan jiwa dan kepribadian peserta didik

(3). Faktor Sarana Prasara

Faktor sarana prasarana yang ada pada kampus Akademi Keperawatan Pemerintah Kabupaten Gresik perlu didayagunakan secara bervariasi sesuai dengan situasi dan kondisi yang ada. Tujuan utama mempergunakan sarana prasarana yang ada diharapkan dapat mencapai hasil yang optimal dalam proses pembudayaan nilai-nilai tersebut 
(4). Faktor Lingkungan

Lingkungan yang kondusif akan menghasilkan secara efektif dalam pembudayaan nilai-nilai tersebut. Kalau faktor lingkungan dalam pembudayaan nilai-nilai yang kurang mendukung maka akan sia-sia. Keselarasan antara pemberian materi tidak berbanding lurus dengan apa yang ada pada lingkungan, apalagi pemberi suri tauladan tidak mampu berperan dengan baik. Tidak bisa digugu lan ditiru

(5) Faktor Goal/Tujuan

Pendidikan agama Islam adalah suatu sistem yang digunakan untuk membentuk manusia yang utuh melalui proses kependidikan. Melalui pembudayaan nilai-nilai diharapkan dapat mencapai suatu tujuan yang telah ditetapkan. Tujuan pendidikan adalah suatu nilai ideal yang hendak diwujudkan melalui proses kependidikan itu. Pendidikan apapun senantiasa kontekstual dengan nilai-nilai atau bahkan komitmen dengan tata nilai

b. Pendekatan Sistem

Model pembudayaan pendekatan ini memiliki pandangan bahwa proses memberi pengaruh, pembentukan pertumbuhan jiwa dan kepribadian dan perkembangan terhadap mahasiswa agar pembudayaan nilai-nilai pendidikan agama Islam berhasil mencapai tujuan yang sangat optimal. Mata kuliah pendidikan agama Islam yang diberikan kepada mahasiswa berlandaskan nilai Islami. Landasan nilai-nilai Islam tersebut berlangsung menurut sistem hukum tertentu. Karakteristik ilmu pendidikan agama Islam adalah sistematis dan konsisten menuju ke arah tujuan yang hendak dicapai.

c. Pendekatan Historis

Model pembudayaan dengan pendekatan historis ini peneliti berupaya mengalisis ilmu pendidikan agama Islam dilihat dari faktafakta sejarah umat Islam yang berawal dari Nabi Muhammad diangkat menjadi Rasulullah SAW. Pendidikan agama Islam berproses berdasarkan pendekatan individual kemudian mengembang ke arah pendekatan keluarga dan berlanjut ke arah pendekatan sosiologis yang semakin meluas ke arah pendekatan nasional dan berpuncak pada pendekatan universal

d. Pendekatan Spiritual

Model pembudayaan pendekatan ini memiliki pandangan bahwa ajaran Islam yang bersumberkan pada kitab suci Al Quran dan sunnah Nabi menjadi sumber impirasi dan motivasi pendidikan agama Islam. Secara prinsipil, Allah SWT telah memberi petunjuk bagaimana agar manusia yang diciptakan sebagai rnakhluk yang memiliki struktur dan kontur psychis dan fisik yang paling sempuma 
dibandingkan dengan makhluk lainnya, dapat berkembang ke arah pola kehidupan yang bertaqwa kepada khalik-Nya, tidak menyimpang ke jalan yang ingkar kepada-Nya. Allah hanya memberikan dua altematif pilihan yaitu jalan hidup yang benar atau jalan hidup yang sesat untuk dipilih oleh manusia melalui pertimbangan akal pikirannya yang dibantu oleh fungsi-fungsi psikologis lainnya. Bila ia memilih jalan kebenaran, maka dijamin oleh Allah akan memperoleh kebahagiaan hidup dunia-akhirat dan bila memilih jalan sesat, maka ia diancam oleh Allah dengan sisksaan-Nya yang menyengsarakan hidupnya di dunia dan akhirat.

Pengembangan pembudayaan nilai multikultural melalui pendidikan agama Islam pada Akademi Keperawatan Pemerintah Kabupaten Gresik diharapkan menggunakan model pengembangan yang bersandar pada Al Quran. Pada prosesnya, mata kuliah pendidikan agama Islam yang menyampaikan kajian nilai-nilai multikultural, para mahasiswa harus dibekali dengan pendidikan karakter tentang nilai-nilai multikultural yang ada dalam kandungan Al Quran. Akademi Keperawatan Pemerintah Kabupaten Gresik merupakan lembaga pencetak profesi keperawatan yang mahasiswanya berasal dari beraneka budaya di antaranya berbeda suku, ras, dan agama.

Nilai-nilai multikultural yang dilakukan oleh mahasiswa Akademi Keperawatan Pemerintah Kabupaten Gresik merupakan nilai-nilai yang amat dibutuhkan oleh dunia keperawatan. Pembudayaan nilai pendidikan agama Islam berbasis multikultural berupaya untuk menanamkan nilai-nilai yang diperlukan dalam konteks masyarakat multikultural. Pengembangan model pembudayaan nilai multikultural tersebut bersandar pada Al Quran di antaranya, nilai yang dimaksud mencakup nilai kasih sayang (Affection), nilai kebersamaan (togetherness), nilai menghargai perbedaan (appreciate the difference), nilai rela berkorban (willing to sacrifice), nilai tenggang rasa atau toleransi (tolerence), dan nilai tolong- menolong (help). Selain itu juga harus memiliki nilai-nilai multikultural solidaritas dan Persaudaraan, kekeluargaan, penghormatan terhadap tatasusila, humaniora, toleransi.

Implikasi dari hasil penelitian ini mencakup dua hal, yaitu implikasi teoritis dan praktis. Implikasi teoritis berhubungan dengan nilai-nilai pendidikan agama Islam yang dikembangkan, proses pembudayaan nilai-nilai pendidikan agama Islam, dan model pembudayaan pendidikan agama Islam berbasis multikultural pada Akademi Keperawatan Pemerintah Kabupaten Gresik. 


\section{KESIMPULAN}

Berdasarkan fokus penelitian, paparan data, dan temuan data serta pembahasan maka hasil penelitian ini dapat disimpulkan sebagai berikut :

1. Nilai pendidikan agama Islam yang dikembangkan pada Akademi Keperawatan Pemerintah Kabupaten Gresik dapat dipresentasikan bahwa dalam (RPS) mata kuliah pendidikan agama Islam dikembangkan dengan memasukkan nilai al-Ikha' (persaudaraan), al-musawah (persamaan), al-tasamuh (toleransi), al-tasyawur (musyawarah), al-ta'awun (tolong menolong) dan al-'adalah (keadilan) dan Nilai sebagai dasar pendidikan agama Islam dalam keperawatan yaitu altruisme, otonomi, human dignity, integritas, adil, estetika, dan kebenaran.

2. Proses pembudayaan nilai pendidikan agama Islam dapat dipresentasikan bahwa proses pembudayaan pendidikan kritis melalui belajar dari realitas/pengalaman, tidak menggurui, dialogis dalam pembelajaran

3. Pembudayaan nilai-nilai pendidikan Agama Islam multikultural

a. Model pembudayaan nilai-nilai pendidikan agama Islam berbasis multikultural diimplementasikan dengan pendekatan sistem, pedagogis-psikologis, historis, dan spiritual

b. Nilai karakter Islam yang berbasis multikultural yang dimaksud mencakup kasih sayang, kebersamaan, menghargai perbedaan, rela berkorban, tenggang rasa, toleransi, dan tolong- menolong. Nilai-nilai tersebut terdapat dalam Al Quran dan Hadits Nabi. Nilai Islam multikultural yang ditanamkan menyangkut beberapa nilai yakni nilai solidaritas dan persaudaraan, nilai kekeluargaan, penghormatan terhadap tatasusila, nilai humaniora, dan nilai toleransi.

\section{DAFTAR PUSTAKA}

A, Doni Koesoema, 2010, Pendidikan Karakter Strategi Mendidik Anak di Zaman Global. Jakarta: PT Gramedia.

Edward Sallis,. 2012, Manajemen Mutu Terpadu Pendidikan. Jogjajakarta: IRCiSoD.

E. Mulyasa, 2009, Manajemen Berbasis Sekolah. Bandung: Rosdakarya.

George R. Terry, 2000, Prinsip-Prinsip Manajemen. (edisi bahasa Indonesia). Bandung: PT. Bumi Aksara.

Haidar Putra Daulay, 2009, Sejarah Pertumbhan dan Pembaruan Pendidikan Islam di Indonesia. Jakarta: Kencana Prenada Media Group, 
Maman Rachman, 1999, Strategi dan Langkah-langkah Penelitian. Semarang: IKIP Semarang Perss.

Muhammad Tholchah Hasan, 2016, Pendidikan Multikultural Sebagai Opsi Penanggulangan Radikalisme. Malang: LembagaPenrbitan UNISMA.

Mujamil Qomar, 2003, Pesantren: dari Transformasi Metodologi Menuju Demokratisasi Institusi. Jakarta: Erlangga.

Noeng Muhajir, 1983, Motede Penelitian Kualitatif, Edisi II, cet. Ke-8, Yogyakarta: Rake Sarasin.

Umiarso dan Nur Zazin. 2011, Pesantren di Tengah Arus Mutu Pendidikan Menjawab Problematika Kontemporer Manajemen Mutu Pesantren. Semarang: Rasail Media Group. 